${ }^{3}$ Wadman, B, and Werner, I, Acta Medica Scandinavica, 1972, 192, 377.

${ }^{4}$ Liang, G C, et al, Arthritis and Rheumatism, 1974, 17, 19.

${ }_{5}^{5}$ Bell, W R, and Klinefelter, H F, fohns Hopkins Medical fournal, 1967, $121,175$.

${ }^{6}$ Liang, G C, and Simkin. P A, Lancet, 1973, 16, 551.

7 Parker, F, Healey, L A W, and Wilske, K K, Arthritis and Rheumatism, $1972,15,449$.

${ }^{8}$ Bacon, P A, Doherty, S M, and Zuckerman, A J, Lancet, 1975, 2, 476.

${ }^{9}$ Hazleman, B L, MacLennan, I C M, and Esiri, M M, Annals of the Rheumatic Diseases, 1975, 1, 1.

1" Dixon, A St J, Fournal of the Royal College of Physicians of London, 1969-70, 4, 55.

1 Hunder, G G, Disney, T F, and Ward, L E, Mayo Clinic Proceedings, $1969, \mathbf{4 4}, 849$.

${ }^{12}$ Rosenthal, M, et al, New England fournal of Medicine, 1975, 292, 595.

13 Terasaki, P I, Healey, L A, and Wilske, K R, New England fournal of Medicine, 1976, 295, 905.

${ }^{14}$ Falchuk, Z M, Rogentine, G N, and Strober, W, fournal of Clinical Investigation, 1972, 51, 1602.

${ }^{15} \mathrm{Katz}, \mathrm{S} \mathrm{I}$, et al, fournal of Clinical Investigation, 1972, 51, 2977.
${ }^{16}$ Fritze, D, et al, Lancet, 1974, 1, 240.

17 Grumet, F C, Payne, R O, and Konishi, J, fournal of Clinical Endocrinology and Metabolism, 1974, 39, 1115.

${ }^{1 *}$ Mackay, I R, and Morris, R J, Lancet, 1972, 2, 793.

19 Platz, P, et al, Lancet, 1974, 2, 289.

20 Singal, D P, and Blajchman, M A, Diabetes, 1973, 22, 429.

${ }^{21}$ Fye, $\mathrm{K} \mathrm{H}$, et al, Arthritis and Rheumatism, 1976, 19, 883.

${ }^{22}$ Thomas, R D, and Croft, N D, British Medical fournal, 1974, 2, 408.

${ }^{23}$ Von Knorring, J, and Somer, T, Scandinavian fournal of Rheumatology, $1974,3,129$.

24 Dausset, J, Degos, L, and Hors, J, Clinical Immunology and Immunopathology, 1974, 3, 127.

${ }^{25}$ Lawler, S D, and Klouda, P T, Histocompatibility Testing, p 555. Copenhagen, Munksgaard, 1972.

${ }^{26}$ Glick, E N, Lancet, 1974, 1, 77.

27 Long, R, and James, O, Lancet, 1974, 1, 77.

${ }^{28}$ Fauchald, P, Rygvold, O, and Oystese, B, Annals of Internal Medicine, $1972,77,845$.

(Accepted 17 August 1977)

\title{
Bacteriological study of otogenic cerebral abscesses: chemotherapeutic role of metronidazole
}

\author{
H R INGHAM, J B SELKON, C M ROXBY
}

British Medical fournal, 1977, 2, 991-993

\begin{abstract}
Summary
In nine consecutive patients with otogenic cerebral abscesses a mixed growth of aerobic and obligate anaerobic bacteria was isolated from the pus in five patients, and in the remaining four obligate anaerobes were the sole isolates. The commonest obligate anaerobe isolated was Bacteroides fragilis, which was present in all but one patient. The patients were all treated with metronidazole for the anaerobic organisms and with appropriate chemotherapy against the aerobic organisms isolated. All the patients recovered and only one was left with a neurological deficit.

As otogenic cerebral abscesses constitute a major proportion of all cerebral abscesses, the use of metronidazole against obligate anaerobic bacteria, which tend to dominate in such abscesses, should reduce the high mortality from this condition.
\end{abstract}

\section{Introduction}

The bacterial flora of cerebral abscesses secondary to chronic infections of the middle ear is usually complex, consisting of a mixture of aerobes and obligate anaerobes. ${ }^{12}$ In the past penicillin has been recommended as the chemotherapeutic agent of choice in such infections, ${ }^{3}$ but its use, often in very high doses, has been accompanied by high mortality rates. ${ }^{2}{ }^{3}$ This is probably due to the frequent presence in such abscesses of Bacteroides fragilis, an obligate anaerobe which is usually highly resistant

Department of Microbiology, Newcastle General Hospital, Newcastle upon Tyne NE4 6BE

H R INGHAM, MRCPATH, DIP BACT, consultant microbiologist

J B SELKON, FRCPATH, DCP, consultant microbiologist

$\mathrm{C} M$ ROXBY, MB, BS, senior registrar in microbiology to penicillin by virtue of drug tolerance and the production of 3-lactamase. ${ }^{45}$

Other agents that have been used for treating cerebral abscesses, such as chloramphenicol and lincomycin, have not always eradicated the infection ${ }^{2} \mathbf{6}$ and are potentially toxic, especially when administered for the long periods that have been traditional in the chemotherapy of these infections. Recently metronidazole has been used to treat the anaerobic bacterial component of this type of cerebral abscess in a few patients. ${ }^{7-9} \mathrm{We}$ describe here the bacteriological findings in nine patients with otogenic cerebral abscesses and the response to treatment with metronidazole.

\section{Patients and methods}

Ten patients were admitted consecutively to the Newcastle regional neurosurgical unit and diagnosed as having an intracranial abscess secondary to chronic middle ear infection. The diagnosis was confirmed and the lesion localised by angiography, ventriculography, and latterly by computerised axial tomography. One patient (case 6) was dead on arrival, having had a cardiac arrest in the ambulance. The remaining nine patients were treated by surgical aspiration of the abscess and in seven cases by the instillation of antibiotics (table I) into the abscess cavity. All the patients were initially treated with metronidazole 400 to $600 \mathrm{mg} 8$ hourly, orally or intravenously, and penicillin $0.6 \mathrm{~g} 6$ hourly or ampicillin $0.5 \mathrm{~g} 6$ hourly and gentamicin $80 \mathrm{mg} 8$ hourly, the regimen being subsequently modified according to the bacterial flora found in the abscess.

\section{BACTERIOLOGY}

Specimens of pus obtained at surgery were inoculated on to $5 \%$ horse blood agar, which was incubated at $37^{\circ} \mathrm{C}$ aerobically for 48 hours and anaerobically for at least 5 days in an atmosphere of $90 \%$ hydrogen and $10 \%$ carbon dioxide in an anaerobic jar fitted with a cold catalyst. In addition, anaerobic cultures were also carried out on horse blood agar containing nalidixic acid at a final concentration of $50 \mu \mathrm{g} / \mathrm{ml}$ to inhibit selectively Gram-negative aerobes. All isolates growing anaerobically were subcultured aerobically and those failing to grow were further examined to determine their sensitivity to metronidazole 
when grown anaerobically by means of a diffusion test using a $5-: \mu \mathrm{g}$ metronidazole disc.

Aerobes and facultative anaerobes were identified according to the criteria described by Cowan and Steel, ${ }^{10}$ and obligate anaerobes were identified according to the methods described by Finegold et al ${ }^{11}$ and Tharagonnet et al. "' Metronidazole assays were carried out by May and Baker using the polarographic method ${ }^{13}$ and in some instances by microbiological assay. ${ }^{6}$

\section{Results}

The bacteriological results for the nine patients are shown in table II. The salient finding is that aerobic bacteria were isolated from only five of the nine patients; these were Proteus mirabilis in four, Escherichia coli in one, Haemophilus influenzae in three, and non-haemolytic streptococci in two. In contrast, anaerobic bacteria were cultured from each patient and at least one species of Bacteroides was consistently present. In eight patients this was Bacteroides fragilis, in the ninth an unidentified Bacteroides species, similar to $B$ fragilis was encountered. $B$ melaninogenicus was also present in five patients. Anaerobic streptococci were the second most common organisms, being present in seven patients. Gram-positive non-sporing bacilli, not yet identified, were present in three patients.

In addition to noting the more frequent occurrence of anaerobic than of aerobic bacteria, we also noticed that $B$ fragilis was invariably present in much larger numbers than the other organisms.

\section{RESPONSE TO TREATMENT}

The age and sex of the nine patients who were treated, the site of the abscess, their state of consciousness, and their treatment are set out in table I. All the patients had single abscesses.

All patients subsequently had a mastoidectomy and in two patients (cases 7 and 8) the abscess capsule was later excised. One of these patients (case 9) had a complicated postoperative course, but, after remaining comatose for many weeks, he finally recovered though he had residual cerebellar ataxia. The other patients all made remarkably rapid recoveries and, when aspiration was repeated after 48 hours, no further growth of bacteria was obtained. All these patients recovered completely without any residual neurological deficit. As experience with metronidazole increased the duration of treatment was reduced; the most recently treated patients (cases 9 and 10) did not have antibiotics instilled into the cavity, and in case 10 systemic chemotherapy was given for only two weeks.

Case 1-This 16-year-old boy, who has been described in detail elsewhere," was of particular interest. He presented with a right cerebellar abscess secondary to chronic middle ear infection. Despite initial excision, mastoidectomy, and successive treatment with peni- cillin, chloramphenicol, lincomycin, and co-trimoxazole, the abscess recurred twice over seven months, the organisms isolated from the original specimen still being present (table II). After the second recurrence resolution was achieved by further drainage and treatment with metronidazole $400 \mathrm{mg} 8$ hourly for four weeks.

\section{METRONIDAZOLE CONCENTRATIONS}

The concentrations of metronidazole achieved in the abscess cavity and in concurrent serum samples after administration of $400 \mathrm{mg}$ or $600 \mathrm{mg} 8$ hourly are set out in table III. As the minimal bactericidal concentration of metronidazole for $B$ fragilis is under $6.25 \mathrm{~kg} \mathrm{gl}$, the concentrations of 34.4 to $45 \mathrm{lg} \mathrm{ml}$, that were reached were satisfactory.

\section{Discussion}

In $1943 \mathrm{McFarlan}{ }^{1}$ pointed out that anaerobic culture was an essential part of the examination of pus from brain abscesses and showed the presence of anaerobes in $35^{\circ}{ }_{\circ}$ of 48 patients examined. But in 1963 Heineman and Braude, 2 in reviewing 15 reports, found that many workers had failed to isolate obligate anaerobic bacteria and that this was usually associated with a high proportion of specimens of pus being reported as sterile on culture. These authors presented a series of 18 consecutive patients with cerebral abscesses and reported that 15 yielded growth of anaerobes, in particular Bacteroides species and anaerobic streptococci. In contrast, Shaw and Russell, ${ }^{14}$ in a review of 47 cases of cerebellar abscesses, reported that anaerobic streptococci were isolated from only four patients. They did, however, point out that Gram-positive cocci were seen on smear examination in nine cases but that no growth was obtained; similarly Gram-negative bacilli were seen in 10 instances but no growth was obtained on culture.

Our finding that obligate anaerobic bacteria were isolated from all our patients has confirmed the suggestion of McFarlan $^{1}$ and Heineman and Braude ${ }^{2}$ that these organisms are important pathogens in brain abscesses, in particular those secondary to chronic middle ear infection, which constitute a major proportion of all cerebral abscesses. Furthermore, we have extended the findings of these earlier studies by identifying the anaerobes more precisely, which has been made possible by recent advances in bacteriological techniques. Improvements in anaerobic culture may have been responsible for our finding that anaerobic bacteria could be isolated from all our patients, but of particular importance was the use of media containing

TABLE I-Details of patients and their chemotherapy

\begin{tabular}{|c|c|c|c|c|c|c|}
\hline $\begin{array}{l}\text { Case } \\
\text { No }\end{array}$ & $\begin{array}{l}\text { Site of } \\
\text { abscess }\end{array}$ & $\begin{array}{l}\text { Age and } \\
\text { sex }\end{array}$ & Preoperative condition & Local antibiotic & $\begin{array}{c}\text { Systemic } \\
\text { chemotherapy }\end{array}$ & $\begin{array}{l}\text { Duration of } \\
\text { chemotherapy }\end{array}$ \\
\hline 1 & Cerebellum & $16 \mathrm{M}$ & Drowsy with epileptic attack & Lincomycin* & Metronidazole & 4 weeks \\
\hline 2 & Temporal lobe & $31 \mathrm{M}$ & Conscious but disorientated with right extensor plantar & Chloramphenicol ${ }^{+}$ & $\begin{array}{l}\text { Chloramphenicol } \\
\text { Metronidazole }\end{array}$ & $\begin{array}{l}8 \text { days } \\
5 \text { weeks }\end{array}$ \\
\hline 3 & " & $25 \mathrm{~F}$ & Conscious with right quadrant hemianopia & $\begin{array}{l}\text { Chloramphenicol } \\
\text { Penicillin }+\end{array}$ & $\begin{array}{l}\text { Gentamicin } \\
\text { Metronidazole }\end{array}$ & $\begin{array}{l}3 \text { weeks } \\
8 \text { weeks }\end{array}$ \\
\hline 4 & ", & $30 \mathrm{~F}$ & Stuporous with right hemiparesis & $\begin{array}{l}\text { Chloramphenicol } \\
\text { Penicillin }\end{array}$ & $\begin{array}{l}\text { Gentamicin } \\
\text { Penicillin } \\
\text { Metronidazole }\end{array}$ & $\left\{\begin{array}{c}10 \text { days } \\
4 \text { weeks }\end{array}\right.$ \\
\hline 5 & " & $40 \mathrm{M}$ & Stuporous with extensor plantars & $\begin{array}{l}\text { Chloramphenicol } \\
\text { Penicillin }\end{array}$ & Metronidazole & 4 weeks \\
\hline 7 & ", & $50 \mathrm{~F}$ & Stuporous with extensor plantars & $\begin{array}{l}\text { Chloramphenicol } \\
\text { Penicillin } \\
\text { Streptomycin } \$\end{array}$ & $\begin{array}{l}\text { Penicillin } \\
\text { Metronidazole }\end{array}$ & \} 4 weeks \\
\hline 8 & $" \quad "$ & $14 \mathrm{~F}$ & Drowsy & $\begin{array}{l}\text { Chloramphenicol } \\
\text { Penicillin } \\
\text { Streptomycin }\end{array}$ & $\begin{array}{l}\text { Ampicillin } \\
\text { Gentamicin } \\
\text { Metronidazole }\end{array}$ & $\begin{array}{c}2 \text { weeks } \\
10 \text { days } \\
3 \text { weeks }\end{array}$ \\
\hline 9 & Cerebellum & $41 \mathrm{M}$ & Unconscious with extensor plantars & Nil & $\begin{array}{l}\text { Ampicillin } \\
\text { Metronidazole }\end{array}$ & $\begin{array}{l}7 \text { weeks } \\
10 \text { days }\end{array}$ \\
\hline 10 & Temporal lobe & $47 \mathrm{M}$ & Unconscious with extensor plantars and fixed pupils & Nil & $\begin{array}{l}\text { Ampicillin } \\
\text { Metronidazole }\end{array}$ & $\begin{array}{l}2 \text { weeks } \\
2 \text { weeks }\end{array}$ \\
\hline
\end{tabular}

*1200 mg. $\$ 5 \mathrm{mg} . ~ \$ 12 \mathrm{mg}$. \$100 mg. 
TABLE II-Bacterial isolates from patients with otogenic cerebral abscesses

\begin{tabular}{|c|c|c|c|c|c|c|c|c|c|}
\hline \multirow[b]{2}{*}{ Bacterial isolates } & \multicolumn{9}{|c|}{ Case No (and site of infection) } \\
\hline & $\begin{array}{c}1 \\
\text { (Cerebellum) }\end{array}$ & $\begin{array}{c}2 \\
\text { (Temporal } \\
\text { lobe) }\end{array}$ & $\begin{array}{c}3 \\
\begin{array}{c}\text { (Temporal } \\
\text { lobe) }\end{array}\end{array}$ & $\begin{array}{c}4 \\
\text { (Temporal } \\
\text { lobe) }\end{array}$ & $\begin{array}{c}5 \\
\begin{array}{c}\text { (Temporal } \\
\text { lobe) }\end{array}\end{array}$ & $\begin{array}{c}7 \\
\begin{array}{c}\text { (Temporal } \\
\text { lobe) }\end{array}\end{array}$ & $\begin{array}{c}8 \\
\text { (Temporal } \\
\text { lobe) }\end{array}$ & (Cerebellum) & $\begin{array}{c}10 \\
\begin{array}{c}\text { (Temporal } \\
\text { lobe) }\end{array}\end{array}$ \\
\hline $\begin{array}{l}\text { Proteus mirabilis } \\
\text { Escherichia coli } \\
\text { Haemophilus influenzae } \\
\text { Non-haemolytic streptococci }\end{array}$ & & $\begin{array}{l}1 \\
1 \\
1\end{array}$ & $\begin{array}{l}1 \\
1\end{array}$ & 1 & obes & & $\begin{array}{l}1 \\
1 \\
1\end{array}$ & & 1 \\
\hline $\begin{array}{l}\text { Bacteroides fragilis } \\
\text { Bacteroides melaninogenicus } \\
\text { Bacteroides oralis } \\
\text { Bacteroides } \mathrm{spp} \\
\text { Fusobacterium necrophorum } \\
\text { Clostridium } \mathrm{spp} \\
\text { Streptoccocci* } \\
\mathrm{GPNSB}^{+}\end{array}$ & $\begin{array}{l}1 \\
1\end{array}$ & $\begin{array}{l}2 \\
1\end{array}$ & $\begin{array}{l}2 \\
1\end{array}$ & $\begin{array}{ll} & \text { Obli } \\
1 & \\
1 & \end{array}$ & $\begin{array}{c}\text { e anaerobes } \\
2 \\
\\
1 \\
1 \\
1 \\
1\end{array}$ & $\begin{array}{l}1 \\
1 \\
1 \\
1 \\
1 \\
1 \\
2\end{array}$ & 1 & $\begin{array}{l}1 \\
2\end{array}$ & 1 \\
\hline
\end{tabular}

*Gram-positive cocci sensitive to metronidazole and failing to grow in $10^{\prime \prime}$, carbon dioxide and air. +Gram-positive non-sporing bacilli.

TABLE III-Medronidazole levels in cerebrospinal fluid and pus from cerebral abscesses. Values in parentheses are concurrent serum levels

\begin{tabular}{|c|c|c|c|c|c|}
\hline \multirow{2}{*}{ Case No } & \multirow{2}{*}{ Dose of metronidazole } & \multirow{2}{*}{ Route of administration } & \multirow{2}{*}{ Material } & \multicolumn{2}{|c|}{ Concentration of metronidazole $(\mu \mathrm{g} / \mathrm{ml})$} \\
\hline & & & & Biological assay & Polarographic assay \\
\hline $\begin{array}{l}4 \\
5 \\
8 \\
9\end{array}$ & $\begin{array}{l}400 \mathrm{mg} 8 \text { hourly } \\
600 \mathrm{mg} 8 \text { hourly } \\
400 \mathrm{mg} 8 \text { hourly } \\
400 \mathrm{mg} 8 \text { hourly }\end{array}$ & $\begin{array}{c}\text { Oral } \\
\text { Intravenous } \\
\text { Oral } \\
\text { Intravenous }\end{array}$ & $\begin{array}{c}\text { Pus } \\
\text { Pus } \\
\text { Pus } \\
\text { Ventricular fluid }\end{array}$ & $\begin{array}{l}21 \cdot 0(14) \\
16 \cdot 8\end{array}$ & $\begin{array}{l}35 \cdot 0(11 \cdot 5) \\
45 \cdot 0(12 \cdot 5) \\
34.4(35 \cdot 1) \\
20 \cdot 7\end{array}$ \\
\hline
\end{tabular}

nalidixic acid. This inhibited aerobic Gram-negative bacteria such as Proteus species that would otherwise have overgrown the more slowly growing anaerobes, in particular $B$ melaninogenicus.

Although Tutton ${ }^{15}$ and Pennybacker ${ }^{16}$ reported mortality rates in patients with otogenic cerebral abscess of $13^{\circ}{ }_{0}$ and $6^{\circ}{ }_{0}$ respectively, the figures subsequently reported by many authors have been much higher. This led the $B M F$ to entitle a leading article on this subject "Unfulfilled Expectations in Cerebral Abscesses." ; For example, Garfield ${ }^{3}$ reported a mortality of $40^{\circ}{ }_{0}$ in 200 patients with supratentorial intracranial abscesses, and Shaw and Russell ${ }^{1+}$ found a mortality of $40^{\circ}{ }^{\circ}$ in 47 patients with cerebellar abscess secondary to chronic infection of the middle ear. The higher mortality rate reported by Garfield $^{3}$ is not explicable in terms of delay in diagnosis or differences in surgical technique. It does, however, seem likely from the case histories presented that there was a further progression of some of the abscesses despite surgical intervention and chemotherapy. This must have been due to the ineffectiveness of their drug of choice, penicillin, against the bacteria causing these abscesses, in particular $B$ fragilis. Garfield instilled only 10000 to 20000 units of penicillin into the abscess cavity, whereas Tutton ${ }^{15}$ and Pennybacker ${ }^{16}$ used 500000 units of penicillin. The resulting very high concentrations of penicillin achieved in the abscess contents by Tutton and Pennybacker might well have been sufficient to kill $\beta$ lactamase producing bacteria that would otherwise be resistant to penicillin. In this respect, it is relevant that many strains of $B$ fragilis produce a highly active $\beta$-lactamase. ${ }^{4}$

Our study has shown that either oral or intravenous administration of metronidazole results in high concentrations of active agent in the pus of cerebral abscesses. This, coupled with the extremely rapid bactericidal activity that has been shown in vitro, ${ }^{1 \times}$ is presumably responsible for the successful clinical and bacteriological results that were obtained. Although only nine patients were studied, three of these were stuporous and two were comatose on admission-preoperative states that in larger studies have been associated with a very high mortality. ${ }^{14} 19$ These results suggest that metronidazole is of prime importance in the chemotherapy of the anaerobic component of otogenic cerebral abscesses, in particular $B$ fragilis. The satisfactory response of our most recently treated patients suggests that chemotherapy for much shorter periods than has been recommended may now be sufficient.

We thank Mr L P Lassman, Professor J Hankinson, Mr M J Betty, Mr R M Kalbag, Mr C Diamond, and Mr I J C Frew for permission to report on their patients.

\section{References}

${ }^{1}$ McFarlan, A M, British Medical fournal, 1943, 2, 643.

' Heineman, H S, and Braude, A I, American fournal of Medicine, 1963, 35, 682.

${ }^{3}$ Garfield, J, British Medical fournal, 1969, 2, 7

${ }^{4}$ Garrod, L P, British Medical fournal, 1955, 2, 1529.

${ }^{5}$ Pinkus, G, Veto, G, and Braude, A I, Fournal of Bacteriology, 1968, 96, 1437.

${ }^{6}$ Ingham, H R, et al, fournal of Antimicrobial Chemotherapy, 1975, 1, 235.

' Ingham, H R, et al, British Medical fournal, 1975, 4, 39.

${ }^{8}$ George, R H, and Bint, A J, fournal of Antimicrobial Chemotherapy, 1976, $2,101$.

${ }_{9}^{9}$ Tally, F P, Sutter, V L, and Finegold, S M, California Medicine, 1972, 117, 22.

${ }^{10}$ Cowan, S T, and Steel, K J, Manual for the Identification of Medical Bacteria. Cambridge, Cambridge University Press, 1974.

${ }^{11}$ Finegold, S M, Harada, N E, and Miller, L G, fournal of Bacteriology, 1967, 94, 1443.

12 Tharagonnet, D, et al, fournal of Clinical Pathology, 1977, 30, 505.

${ }^{13}$ Kane, P O, fournal of the Polarographic Society, 1961, 7, 58.

${ }^{14}$ Shaw, M D M, and Russell, J A, fournal of Neurology, Neurosurgery and Psychiatry, 1975, 38, 429.

15 Tutton, G K, Annals of the Royal College of Surgeons of England, 1953, 13, 281.

${ }^{16}$ Pennybacker, J, Proceedings of the Royal Society of Medicine, 1961, 54, 309.

17 British Medical fournal, 1969, 2, 1

18 Whelan, J P F, and Hale, J H, fournal of Clinical Pathology, 1973, 26, 393.

19 Carey, M E, Chou, S N, and French, L A, Fournal of Neurosurgery, 1972, 36, 1 .

(Accepted 24 August 1977) 